\title{
SOYBEAN INTEGRATED PEST MANAGEMENT FOR PROMOTING SUSTAINABLE AGRICULTURE UNDER CLIMATE CHANGE
}

\author{
Felicia Mureșanu ${ }^{1}$, Dana Malschi ${ }^{1}$, Loredana Suciu ${ }^{1,2 *}$, Felicia Chețan ${ }^{1}$, Camelia Urdă ${ }^{1}$, \\ Laura Șopterean ${ }^{1}$, Ana-Maria Vălean ${ }^{1}$, Vasile Oltean ${ }^{1}$, Gabriel Barșon, ${ }^{2}$, Florin Russu ${ }^{1}$ \\ ${ }^{1}$ Agricultural Research and Development Station Turda \\ ${ }^{2}$ University of Agricultural Sciences and Veterinary Medicine, Faculty of Agriculture, Cluj \\ Napoca
}

\author{
*Corresponding author: \\ Agricultural Research and Development Station Turda \\ 27 Agriculturii Street, 401100, Turda, Cluj, Romania \\ Tel:+40264311680(1) \\ Fax:+40264311792 \\ E-mail:suciualexandra1@yahoo.com
}

http://www.doi.org/10.54574/RJPP.13.02

\begin{abstract}
In order to protect agroecosystems and to optimize soybean crop yield from the Transylvanian Plain, the adoption of complex methods of sustainable management with minimal impact on the environment has now become a challenge. Therefore, an experiment was conducted at the Agricultural Research-Development Station Turda in 2018, to provide the best methods for the development of an Integrated Management System (IMS) for phytosanitary soybean crop risks. The field factorial experiment was based on a subdivided parcel design with two replications. Experimental models for soybean crop protection have been developed. Field research was carried out for analyzing the technological (agricultural practices), biological (diseases, insects, pests) and environmental (climate change, methods of improving soil fertility with phytosanitary risk by applying environmentally friendly products) factors affecting soybean crop yield and quality. An entomological sampling strategy (pheromone traps, plant surveys) was used for evaluating the IMS environmental risk and methods for increasing plant resistance to biotic and abiotic stress factors were also studied. The obtained data was correlated with the production values for the 3 experimental factors: the tillage system, fertilization and treatments. The following pests were recorded, soil pests Coleoptera, Agriotes larvae, Opatrum, dipterans Delia platura and D. florilega, vectors of viruses and phytoplasmoses, cicadas, aphids, trips and the common red spider Tetranychus urticae, defoliating omissions Vanessa cardui, owls Autographa gamma, Mamestra suasa, M. oleracea, Agrotis segetum) etc. In the climatic conditions of 2018, most frequent pathogens were downy mildew (Peronospora manshurica and bacterial blight Pseudomonas glycinae.
\end{abstract}

Keywords: soybean, climate change, integrated management, pests

\section{INTRODUCTION}

Climate change, microclimatic changes caused by global warming, regional agroecological conditions, the changes in tillage technologies and the division into smaller units of the areas belonging to agricultural holdings (Ignea, 2017) cause significant losses to agricultural production worldwide. As a result of all these factors, pest populations, weeds and disease dynamics became unstable and affect the global crop production. In order to ensure increased yield and production security, it is necessary to perform a systemic approach of research regarding integrated control strategies, based on new methods which are efficient and suitable for technological and climate change.

In new farm types, the use of natural environmentally friendly activities, that do not cause imbalances that irreversibly damage the ecosystem, corrected as much as possible the relationship between the plants and the ecosystem. Compared to intensive agricultural holdings, in new farms, the relationships between plant-soil and biotope-biocenosis are analyzed taking into account the complexity of agro-ecological factors. In order to correct or 
optimize the environmental conditions, non-invasive agrotechnical methods, which consist in the rational use of chemicals, are applied.

The soybean yield, yield elements and nodules development are influenced by the applied tillage system. In some cases no-tillage or minimum tillage system is recommended. By applying these systems on fertile, structured soils, the yield increased with 2-15\% compared to the conventional tillage system. On less fertile, compact soils, with humus contents below $2.2 \%$, with a great textural differentiation on the soil profile (preluvosol, luvosol), minimum tillage and no-tillage reduce the production. Conservative agriculture should ensure yields close to conventional agriculture, with a minimum impact on the environment, through optimal energy and economic efficiency. This includes a series of complementary agricultural practices: (i) minimum tillage (through a minimal tillage system or direct seed drill) for improving soil structure, fauna and organic matter; (ii) permanent soil cover (cover crops, residue cover and mulch) to protect the soil, improve drainage and contribute to weed control; (iii) different crop rotations and combinations which stimulate soil microorganisms and support pest, weed and disease control (Cheţan et al., 2014, 2016, 2017).

Soybean shows special sensitivity to weeding in the early growth and at the beginning of maturity. When weeding occurs in the first stages of development, the crop cannot be saved by the subsequent control weeds. Soybean is a small to medium-height plant being easily overcome by weeds with high yield loss (30-80\%), sometimes even compromising the crop (Berca, 2004; Avola et al., 2008). The most common weeds in soybean crops are especially the ones that germinate in late spring (Sartorato et al., 1996; Rusu, 2014): Echinochloa crusgalli, Setaria sp., Digitaria sanguinalis, Sorghum halepense, Agropyron repens, Solanum nigrum, Amaranthus retroflexus, Chenopodium album, Galinsoga parviflora, Xanthium sp., Abutilon teophrasti, Datura stramonium, Polygonum sp., Cirsium arvense, Convolvulus arvensis (Cheţan et al., 2019; Gradila, 2016, 2017)

Recent studies highlight that crop rotation, management of diseases and pests seriously affect soybean crops. Soybean diseases can be caused by viruses, bacteria and fungi. Viral diseases such as: soybean mosaic virus, tobacco ringspot virus, yellow mosaic virus can decrease yield with more than $25 \%$. Principal bacterial disease are bacterial blight, bacterial pustule and stem wilt. The most widespread micoses of soybean are downy mildew, brown spot on the leaves, anthracnose, root and stem rot, stem rot or white mold, pod and stem blight or stem canker and purple seed stain (Suciu et al., 2014).

In the agro-ecosystems of soybean crops in central Transylvania, the soil pest attacks were highlighted: worm's wire and darkling beetle, European mole cricket, sowing owls, earth fleas, mites (Mureșanu et al, 1989, 1998, 2002, 2014; Mureșanu \& Tărău, 2013; Georgescu et al., 2016; Ivaș \& Mureșanu, 2011, 2013; Malschi et al., 2013, 2017; Popov et al, 2003; Trotuş et al., 2014). In soybean and bean crops, attacks of: dipterans (Mustea \& Tătaru, 1970; Malschi, 1980, 2009; Perju \& Malschi, 2001), aphids and cicadas (Malschi, 2009; Malschi et al., 2013), painted lady and especially the mite T. urticae (with attack frequency between 30-50\%) (Mureşanu \& Tărău, 2013; Mureşanu et al., 2014), have also been reported. In 2016, the invasive presence of Vanessa cardui was reported. This species may be a real danger for the soybean crop, because the larvae are very voracious, consuming the entire leaf language of the leaf, leaving only the nerves intact. The research reveals the existence of a entomophagous arthropods limiting the phytophagous insects, the known groups of entomophageal auxiliaries being reported: Aranea, Dermaptera, Aeolothripidae, Nabidae, Sylphidae, Coccinellidae, Carabidae, Cicindelidae, Staphylinidae, Cantharidae, Malachiidae, Syrphidae, Scatophagidae, Empididae, Formicidae, Chrysopidae (Malschi \& Mustea, 1995, 1997; Malschi, 2007, 2009, 2014; Malschi et al., 2017, 2018). 


\section{MATERIAL AND METHODS}

In order to limit the attack of diseases and pests, the conservative agriculture components and technological measures, adapted to climate change, were studied in a polyfactorial experiment. The trials were carried out at Agricultural Research and Development Station Turda (ARDS Turda) in 2018. TEO TD, an early soybean variety developed at ARDS Turda was used as a biological material. To achieve the experiment objectives, following factors were studied:

The tillage system

- ploughing at a depth of $30 \mathrm{~cm}: 12.11 .2017$

- chisel plough processing at $30 \mathrm{~cm}$ depth: 12.11 .2017

- disk harrow processing at $12 \mathrm{~cm}$ depth: 12.11.2017

- preparation of seedbed in spring with rotary harrow: 19.04.2018

- sowing: 24.04.2018

- $\quad$ sowing density: $45 \mathrm{bg} / \mathrm{m}^{2}$

- $\quad$ seed quantity/ha: $69 \mathrm{~kg} / \mathrm{ha}$; incorporation depth of seeds: $4 \mathrm{~cm}$

- distance between rows: $18 \mathrm{~cm}$ (with Gaspardo Directa 400 seed drill)

Weed, disease and pest control: (i) preemergent herbicide application: 23.04.2018 with Sencor 0,35 1/ha + Frontier 1,4 1/ha +2601 water; (ii) postemergent herbicide application: 30.05.2018 with Corum 1,9 1/ha +2601 water (for dicotiledonate); 01.06 .2018 with Agil 1.0 1/ha (for monocotiledonate); (iii) phytosanitary treatments: 02.07.2018: COPFORT 3 1/ha (fungicide) and FASTER $100 \mathrm{ml} / \mathrm{ha}$ (insecticide).

Fertilization: (i) fertilization level: $\mathrm{N}_{40} \mathrm{P}_{40} \mathrm{~kg}$ s.a./ha at the same time as the sowing; (ii) organic gulle fertilizer before the sowing $+\mathrm{N}_{40} \mathrm{P}_{40}$ at the same time as the sowing; (iii) green fertilizer, precursory to the soybean crop + gulle before sowing $+\mathrm{N}_{40} \mathrm{P}_{40}$, at the same time as the sowing.

Observations and determinations/ conclusions during the vegetation period:

- emergence of the plants occurred at 7.05.2018 at a density of: $11 \mathrm{pl} / \mathrm{m}^{2}$ (in ploughed land), $9 \mathrm{pl} / \mathrm{m}^{2}$ (in land processed with chisel plough), $6 \mathrm{pl} / \mathrm{m}^{2}$ (in land processed with disk harrow), $3 \mathrm{pl} / \mathrm{m}^{2}$ (in untilled land- drought caused very poor sprouting of the crop). After May rainfalls (between $17^{\text {th }}-21^{\text {st }}$ ) more seeds germinated and emergence occurred in steps, leading to uneven and staggered soybean emergence; the different development stages of plants (1-3 trifoliate leaves, 2 simple (unifoliate) leaves and in the cotyledon stage), created difficulties in applying post-emergence treatments for weed control.

- the research system, determinations in dynamics and the measurements to be performed were planned;

- plant density before flowering (at 21.05.2018): $37 \mathrm{pl} / \mathrm{m}^{2}$ in ploughed land, $35 \mathrm{pl} / \mathrm{m}^{2}$ after chisel plough processing, $31 \mathrm{pl} / \mathrm{m}^{2}$ in land processed with disk harrow and $24 \mathrm{pl} / \mathrm{m}^{2}$ in untilled land;

- beginning of flowering occurred at 21.06.2018;

- number of nodules/ plant was determined between 22.06.2018-28.06.2018;

- for monitoring and limiting the attack of some lepidoptera during the soybean growing stages, synthesis sex pheromone traps were placed on 29.05.2018;

- evaluation of disease and of the two-spotted spider mite attack: 01-03.08.2018.

Harvesting and quantitative and qualitative evaluation of the yield was accomplished:

- date of harvesting: 09.10.2018. 


\section{RESULTS AND DISCUSSION}

From the point of view of pest attack on the soybean crop in 2018, no alarming dangerous levels or significant loss caused by the main pest types were registered. From previous years' observations, the importance of the attack potential of soil-dwelling pest species is well-known: Coleoptera larvae (Agriotes spp., Opatrum spp.), cook chafer larvae Scarabeidae, Lepidoptera Noctuidae caterpillars (Agrotis segetum), caterpillars of soildwelling pests Gryllotalpa, Gryllus, Delia platura and D. florilega, some nematodes and important vectors of viruses and phytoplamas - cicadas, aphids, trips and especially the twospotted spider mite Tetranichus urticae, defoliating insects larvae - the thistle caterpillar Vanessa cardui, moths larvae of A. segetum, Autographa gamma, Mamestra suasa and M. oleracea as well as other flower, pod and grain pests larvae (Curculionidae, Chrysomelidae). Entomophagous arthropods which actively limit soybean crop pests were also reported in central Transylvania.

The climatic and technological crop conditions, abundance, the dynamics and structural interactions of pests and the natural fund of entomphagous auxiliaries from the agroecosystems originating from cereal crop rotation represent influential factors with a high degree of impact on the formation of soybean production.

The main pests reported in 2018 were the species of harmful Lepidoptera: A. segetum, A. gamma, M. suasa, M. oleracea, T. urticae and Agriotes spp.

In the experimental field, the monitoring and limitation of some lepidoptera was performed through the use of pheromone traps, placed when emergence occurred. The pheromone was changed monthly for each species and the tags/ plates were read weekly.

The silver-Y moth A. gamma recorded a maximum flight at the end of May (8 adults in the disk harrow processing system) and the second maximum flight in the first decade of September (29 adults in the no tillage system) (Figure. 1).

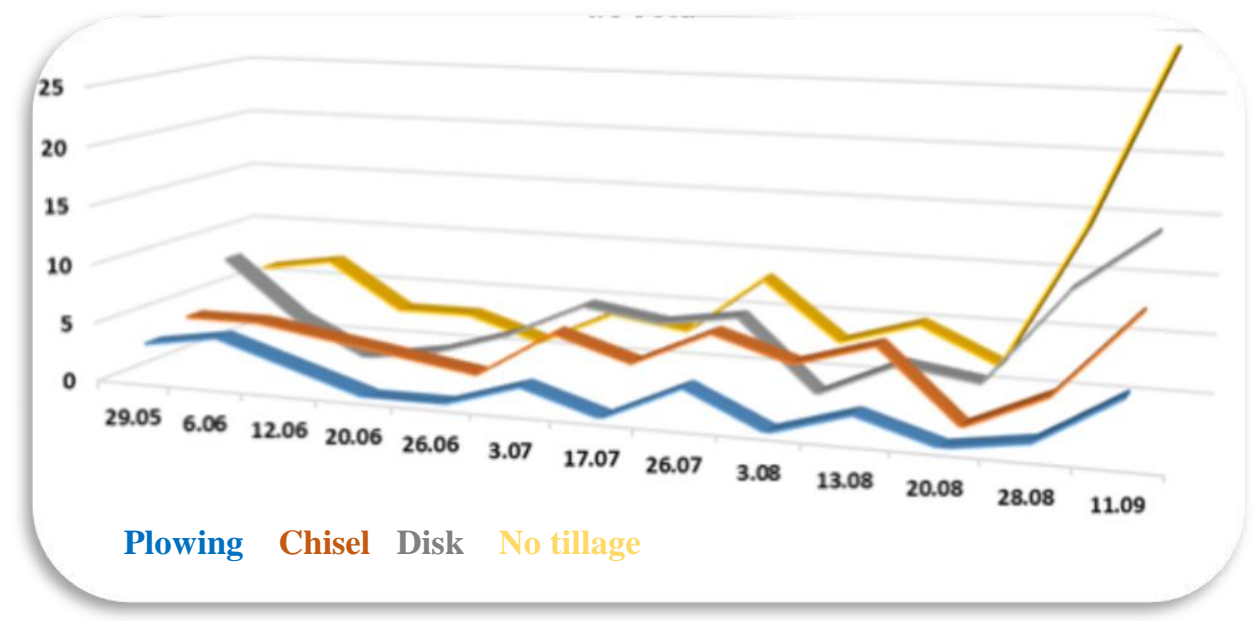

Figure 1. The dynamics of Autographa gamma adult flight

The appearance of butterflies of A. segetum is mainly recorded in early May and is observed until the beginning of July. The mass flight of butterflies ( 26 adults in the no tillage system) coincides with the last decade of May. The second-generation of butterfly appears, at the end of July - beginning of August (32 adults in the no tillage system), and at the beginning of September the maximum captured individuals are registered (33 adults in the no tillage system) (Figure 2). 


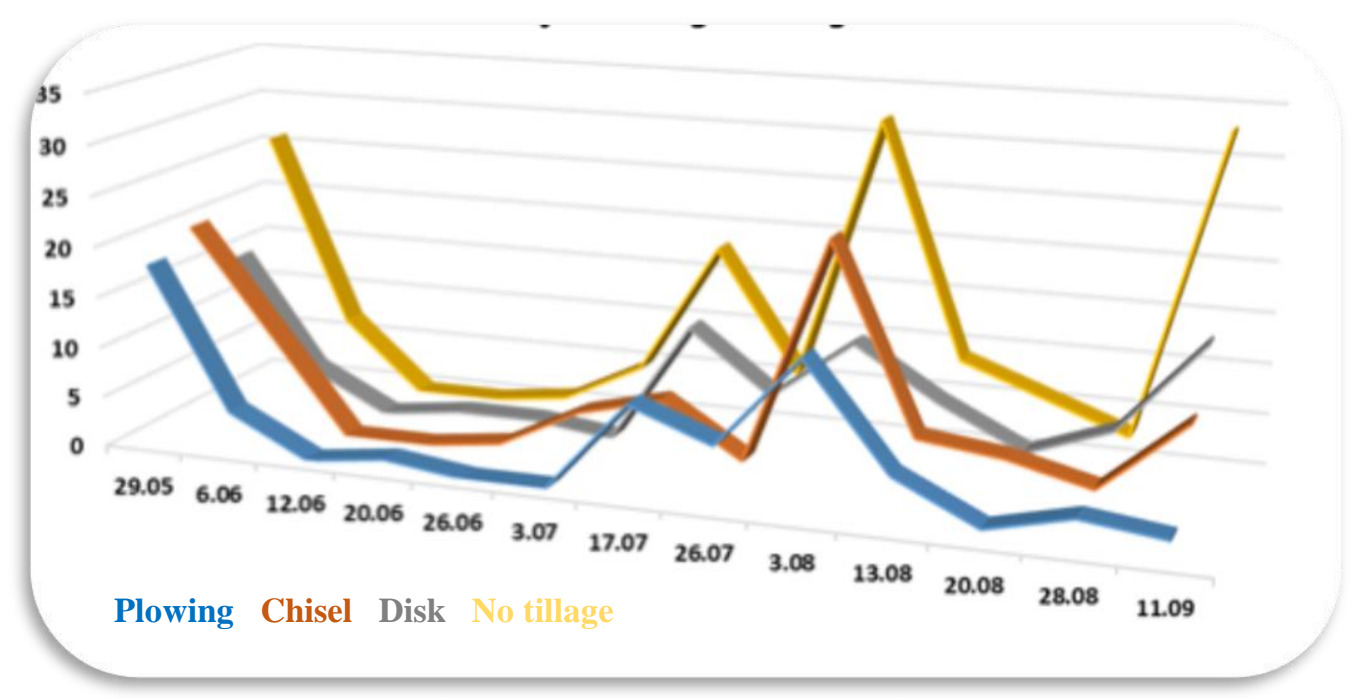

Figure 2. The dynamics of Agrotis segetum adult flight

At the pheromone traps for the M. suasa species, the adults appeared in the crop starting with May, with a maximum number of adults in the third decade of June (11 adults in the disk harrow processing system), then the flight diminished (Figure. 3).

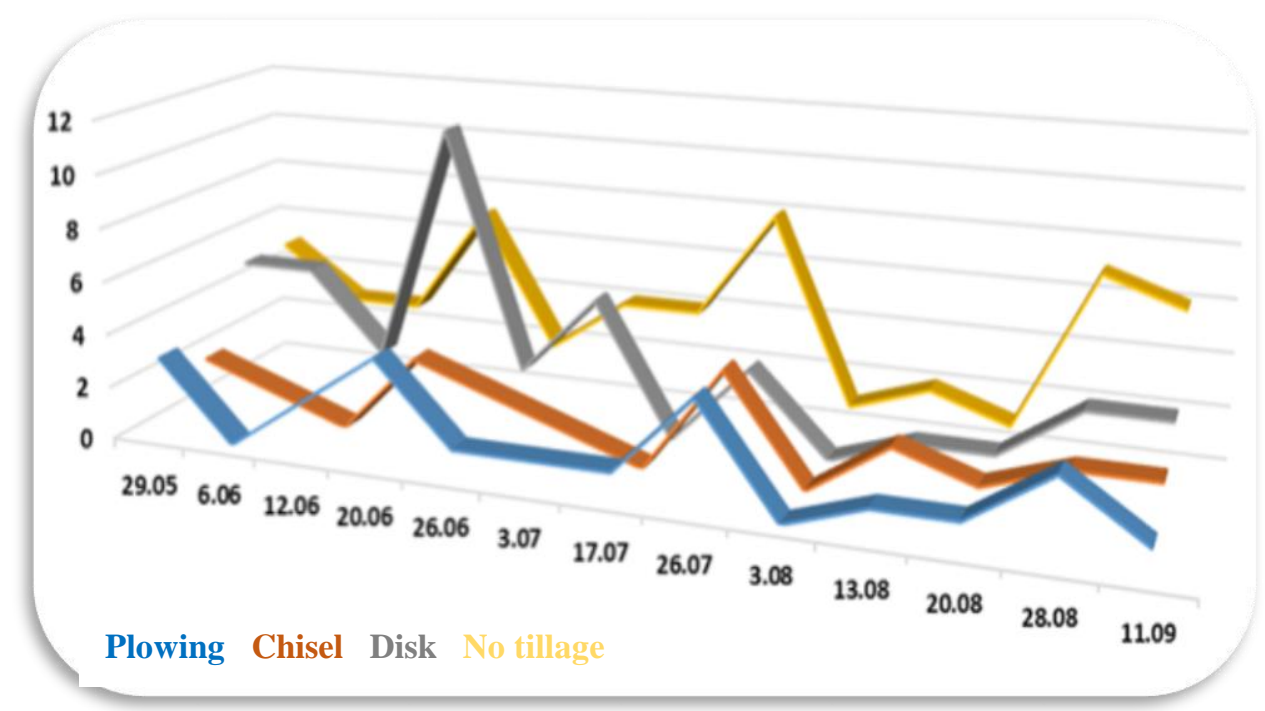

Figure 3. The dynamics of $M$. suasa adult flight

The cabbage moth $M$. oleracea had the following dynamics in the soybean crop: it appeared in the crop in May, with a reduced number of adults during the whole monitored period in 2018, most individuals being captured in the no tillage system (Figure 4). 


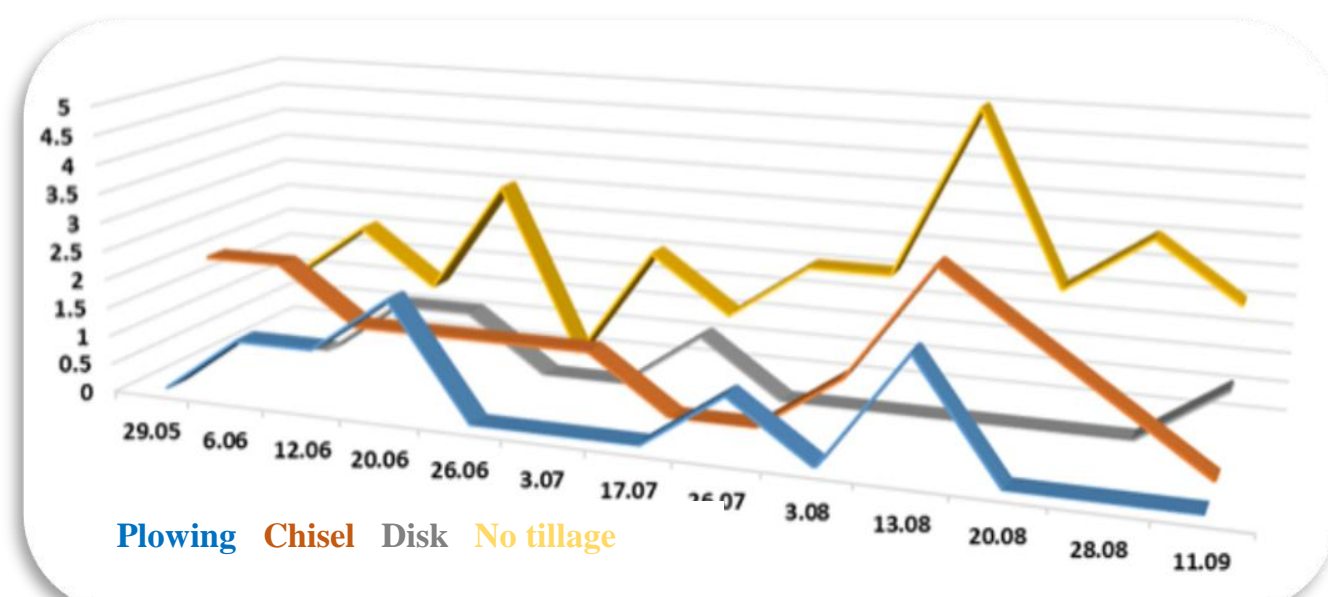

Figure 4. The dynamics of Mamestra oleracea adult flight

For the above-mentioned Lepidoptera, the biggest number of captured adults with synthesis sex pheromone traps was recorded in the no tillage system, followed by the disk harrow processing system; from among the studied species, the greatest abundance goes to the A. segetum (turnip moth) species.

The spider mite T. urticae is one of the most important pests of soybean crop because of the damage it causes. The affected leaves may dry and drop from the plant and plants defoliate with continued two-spotted spider mites pressure. The density of T. urticae in the soybean crop was determined by counting the number of insects of the plant. The biggest number of individuals was recorded in the no tillage system where supplementary fertilization with gulle was applied (Table 1).

Table 1. The density of Tetranichus urticae in soybean

\begin{tabular}{|c|c|c|c|c|c|}
\hline \multirow{3}{*}{$\begin{array}{c}\text { SOIL } \\
\text { TILLAGE } \\
\text { SYSTEM }\end{array}$} & \multirow{3}{*}{ FERTILIZATION } & \multicolumn{4}{|c|}{ THE AVERAGE NUMBER OF SPIDERS / PLANT } \\
\hline & & \multicolumn{4}{|c|}{ TREATMENTS } \\
\hline & & $\begin{array}{l}\text { UNTREA } \\
\text { TED }\end{array}$ & $\begin{array}{l}\text { FUNGICI } \\
\text { DE }\end{array}$ & $\begin{array}{l}\text { INSECTICI } \\
\text { DE } \\
\end{array}$ & $\begin{array}{l}\text { FUNGICIDE + } \\
\text { INSECTICIDE }\end{array}$ \\
\hline \multirow{4}{*}{ CLASSIC } & $\mathrm{N}_{40} \mathrm{P}_{40}$ & 54 & 65 & 60 & 53 \\
\hline & $\mathrm{N}_{40} \mathrm{P}_{40}+$ GULLE & 94 & 122 & 76 & 100 \\
\hline & $\begin{array}{l}\mathrm{N}_{40} \mathrm{P}_{40}+\text { GREEN } \\
\text { FERTILIZER }\end{array}$ & 58 & 67 & 72 & 55 \\
\hline & $\begin{array}{l}\mathrm{N}_{40} \mathrm{P}_{40}+\text { GULLE }+ \\
\text { GREEN FERTILIZER }\end{array}$ & 95 & 121 & 78 & 101 \\
\hline \multirow{4}{*}{$\begin{array}{l}\text { MINIMUM } \\
\text { TILLAGE } \\
\text { CHISEL }\end{array}$} & $\mathrm{N}_{40} \mathrm{P}_{40}$ & 77 & 62 & 50 & 69 \\
\hline & $\mathrm{N}_{40} \mathrm{P}_{40}+$ GULLE & 140 & 66 & 99 & 130 \\
\hline & $\begin{array}{l}\mathrm{N}_{40} \mathrm{P}_{40}+\text { GREEN } \\
\text { FERTILIZER }\end{array}$ & 78 & 79 & 50 & 70 \\
\hline & $\begin{array}{l}\mathrm{N}_{40} \mathrm{P}_{40}+\mathrm{GULLE}+ \\
\text { GREEN FERTILIZER }\end{array}$ & 138 & 69 & 100 & 129 \\
\hline \multirow{4}{*}{$\begin{array}{l}\text { MINIMUM } \\
\text { TILLAGE } \\
\text { DISK }\end{array}$} & $\mathrm{N}_{40} \mathrm{P}_{40}$ & 49 & 60 & 57 & 51 \\
\hline & $\mathrm{N}_{40} \mathrm{P}_{40}+$ GULLE & 89 & 109 & 81 & 89 \\
\hline & $\begin{array}{l}\mathrm{N}_{40} \mathrm{P}_{40}+\text { GREEN } \\
\text { FERTILIZER }\end{array}$ & 52 & 62 & 67 & 56 \\
\hline & $\begin{array}{l}\mathrm{N}_{40} \mathrm{P}_{40}+\text { GULLE }+ \\
\text { GREEN FERTILIZER }\end{array}$ & 90 & 109 & 83 & 90 \\
\hline \multirow{2}{*}{$\begin{array}{c}\text { NO } \\
\text { TILLAGE }\end{array}$} & $\mathrm{N}_{40} \mathrm{P}_{40}$ & 91 & 81 & 76 & 91 \\
\hline & $\mathrm{N}_{40} \mathrm{P}_{40}+$ GULLE & 150 & 118 & 133 & 168 \\
\hline
\end{tabular}




\begin{tabular}{|l|l|c|c|c|c|}
\hline & $\begin{array}{l}\mathrm{N}_{40} \mathrm{P}_{40}+\text { GREEN } \\
\text { FERTILIZER }\end{array}$ & 97 & 92 & 80 & 92 \\
\cline { 2 - 5 } & $\begin{array}{l}\mathrm{N}_{40} \mathrm{P}_{40}+\text { GULLE + } \\
\text { GREEN FERTILIZER }\end{array}$ & 148 & 118 & 132 & 165 \\
\hline
\end{tabular}

Disease rating by visual observation indicated that for soybean crop, in 2018, low infection pressure has been reported in all 4 tillage systems, with downy mildew (Peronospora manshurica) and bacterial blight (Pseudomonas glycinae) attacks.

The highest frequency pathogen in the agricultural year 2018 was $P$. manshurica. From the data obtained we can conclude that the frequency of attack was over $30 \%$, but with an intensity not exceeding $2 \%$, which led to a degree of attack below $2 \%$ in all the experimental variants (Table 2 ).

Table 2. The frequency and intensity of the $P$. manshurica attack

\begin{tabular}{|c|c|c|c|c|c|c|c|c|c|}
\hline \multirow{3}{*}{$\begin{array}{l}\text { TILLAGE } \\
\text { SOIL } \\
\text { SYSTEM }\end{array}$} & \multirow{3}{*}{ FERTILIZATION } & \multicolumn{8}{|c|}{ TREATMENTS } \\
\hline & & \multicolumn{2}{|c|}{$\begin{array}{l}\text { UNTREA } \\
\text { TED }\end{array}$} & \multicolumn{2}{|c|}{$\begin{array}{l}\text { FUNGICI } \\
\text { DE }\end{array}$} & \multicolumn{2}{|c|}{$\begin{array}{l}\text { INSECTIC } \\
\text { IDE }\end{array}$} & \multicolumn{2}{|c|}{$\begin{array}{c}\text { FUNGICID } \\
\text { E + } \\
\text { INSECTICI } \\
\text { DE }\end{array}$} \\
\hline & & $\mathrm{F} \%$ & $\mathrm{I} \%$ & F\% & $\mathrm{I} \%$ & $\mathrm{~F} \%$ & $\mathrm{I} \%$ & F\% & $\mathrm{I} \%$ \\
\hline \multirow{4}{*}{ CLASSIC } & $\mathrm{N}_{40} \mathrm{P}_{40}$ & 50 & 0.74 & 44 & 0.34 & 57 & 0.59 & 48 & 0.44 \\
\hline & $\mathrm{N}_{40} \mathrm{P}_{40}+$ GULLE & 58 & 0.94 & 51 & 0.54 & 64 & 0.79 & 55 & 0.64 \\
\hline & $\mathrm{N}_{40} \mathrm{P}_{40}+$ GREEN FERTILIZER & 55 & 0.69 & 35 & 0.19 & 62 & 0.44 & 47 & 0.29 \\
\hline & $\begin{array}{l}\mathrm{N}_{40} \mathrm{P}_{40}+\text { GULLE + GREEN } \\
\text { FERTILIZER }\end{array}$ & 61 & 1.32 & 44 & 0.87 & 64 & 1.12 & 52 & 0.97 \\
\hline \multirow{4}{*}{$\begin{array}{l}\text { MINIMUM } \\
\text { TILLAGE } \\
\text { CHISEL }\end{array}$} & $\mathrm{N}_{40} \mathrm{P}_{40}$ & 34 & 1.23 & 41 & 0.68 & 40 & 1.63 & 40 & 0.73 \\
\hline & $\mathrm{N}_{40} \mathrm{P}_{40}+$ GULLE & 41 & 1.63 & 48 & 0.88 & 37 & 1.62 & 47 & 0.93 \\
\hline & $\mathrm{N}_{40} \mathrm{P}_{40}+$ GREEN FERTILIZER & 40 & 1.28 & 29 & 0.53 & 48 & 1.28 & 50 & 0.58 \\
\hline & $\begin{array}{l}\mathrm{N}_{40} \mathrm{P}_{40}+\text { GULLE + GREEN } \\
\text { FERTILIZER }\end{array}$ & 41 & 1.96 & 39 & 1.21 & 43 & 1.95 & 49 & 1.26 \\
\hline \multirow{4}{*}{$\begin{array}{l}\text { MINIMUM } \\
\text { TILLAGE } \\
\text { DISK }\end{array}$} & $\mathrm{N}_{40} \mathrm{P}_{40}$ & 40 & 0.97 & 53 & 0.43 & 40 & 1.03 & 42 & 0.43 \\
\hline & $\mathrm{N}_{40} \mathrm{P}_{40}+$ GULLE & 47 & 1.17 & 60 & 0.63 & 47 & 1.23 & 49 & 0.63 \\
\hline & $\mathrm{N}_{40} \mathrm{P}_{40}+$ GREEN FERTILIZER & 43 & 0.82 & 40 & 0.28 & 48 & 0.88 & 45 & 0.28 \\
\hline & $\begin{array}{l}\mathrm{N}_{40} \mathrm{P}_{40}+\text { GULLE + GREEN } \\
\text { FERTILIZER }\end{array}$ & 46 & 1.50 & 51 & 0.96 & 48 & 1.56 & 48 & 0.96 \\
\hline \multirow{4}{*}{$\begin{array}{c}\text { NO } \\
\text { TILLAGE }\end{array}$} & $\mathrm{N}_{40} \mathrm{P}_{40}$ & 44 & 1.90 & 60 & 0.64 & 46 & 1.37 & 48 & 0.82 \\
\hline & $\mathrm{N}_{40} \mathrm{P}_{40}+$ GULLE & 51 & 1.53 & 67 & 0.84 & 53 & 1.37 & 40 & 1.02 \\
\hline & $\mathrm{N}_{40} \mathrm{P}_{40}+$ GREEN FERTILIZER & 58 & 0.95 & 55 & 0.49 & 55 & 1.02 & 60 & 0.67 \\
\hline & $\begin{array}{l}\mathrm{N}_{40} \mathrm{P}_{40}+\text { GULLE + GREEN } \\
\text { FERTILIZER }\end{array}$ & 55 & 1.74 & 62 & 1.17 & 55 & 1.70 & 51 & 1.35 \\
\hline
\end{tabular}

The highest values were recorded for the minimum tillage system experimental variant. On the other hand, when Copfort was applied, small values correlated with high yield were obtained. In order to increase plant resistance to biotic and abiotic stress factors, Copfort was applied according to the experimental model presented above (doses of $3 \mathrm{l} / \mathrm{ha}$ at the beginning of flowering). The product is a fortifier for plants and protection inductor and acts simultaneously in several areas of the plant as a fortifier and under biotic or abiotic stress circumstances. It is a copper-based aqueous solution complex with gluconic acid which induces natural resistance to the plant. The copper gluconate from Copfort easily permeates the cuticle and induces the synthesis of phytoalexins in the plant which inhibit hyphal growth of fungi or the multiplication of bacteria. The generated phytoalexins are usually terpenoid; due to its systemic effect, the product acts at the whole plant level (including the roots). 
Weeds infestation of agricultural crops is a dynamic process and represents the qualitative and quantitative expression of the influence of the soil seeds stock, the changes in plant cultivation technology and the weed control management (Gradila, 2018).

During the experiment, the weeding degree of the soybean crop was determined according to the tillage system. Before the application of postemergent herbicide, the following weeds were identified: monocotiledonate Echinochloa crus galli; and dicotiledonate: Xanthium strumarium, Hibiscus trionum, Chenopodium album, Sonchus arvensis, Cirsum arvense, Polygonum convolvulus, P. aviculare, Rubus caesius, Viola arvensis (Table 3).

Table 3. Weed species present in soybean culture in 2018

\begin{tabular}{|c|c|c|c|c|c|c|c|c|c|}
\hline \multirow[t]{2}{*}{ No. } & \multirow[t]{2}{*}{ Weed species } & \multicolumn{4}{|c|}{$\begin{array}{c}\text { Soil system tillage } \\
\text { weeds number/ } \mathrm{m}^{2} \\
\text { before treatents }(30.05 .2018)\end{array}$} & \multicolumn{4}{|c|}{$\begin{array}{c}\text { Soil system tillage } \\
\text { weeds number/ } \mathrm{m} 2 \\
\text { at } 14 \text { days after treatments }(12.06 .2018)\end{array}$} \\
\hline & & Plowing & Chisel & Disk & $\begin{array}{c}\text { No } \\
\text { tillage }\end{array}$ & Plowing & $\begin{array}{c}\text { Chise } \\
1\end{array}$ & Disk & $\begin{array}{c}\text { No } \\
\text { tillage }\end{array}$ \\
\hline 1. & X. strumarium & 4 & 3 & 0 & 3 & 4 & 3 & 0 & 3 \\
\hline 2. & Che. album & 8 & 9 & 14 & 7 & 8 & 9 & 14 & 7 \\
\hline 3. & P. convolvulus & 3 & 1 & 0 & 1 & 3 & 1 & 0 & 1 \\
\hline 4. & P. aviculare & 0 & 0 & 0 & 2 & 0 & 0 & 0 & 0 \\
\hline 5. & S. arvensis & 0 & 0 & 0 & 2 & 0 & 0 & 0 & 2 \\
\hline 6. & R. caesius & 0 & 1 & 0 & 0 & 0 & 1 & 0 & 0 \\
\hline 7. & C. arvense & 0 & 0 & 0 & 1 & 0 & 0 & 0 & 1 \\
\hline 8. & V. arvensis & 0 & 3 & 3 & 6 & 0 & 0 & 0 & 0 \\
\hline 9. & H. trionum & 0 & 1 & 2 & 0 & 0 & 1 & 2 & 0 \\
\hline 10. & E. cruss galli & 3 & 3 & 4 & 6 & 0 & 0 & 0 & 0 \\
\hline 11. & D. carota & 0 & 0 & 0 & 2 & 0 & 0 & 0 & 0 \\
\hline \multicolumn{2}{|c|}{ Total } & 18 & 21 & 23 & 30 & 15 & 15 & 16 & 14 \\
\hline
\end{tabular}

The weeding degree of the soybean crop in 2018 before herbicides treatment was higher in the minimum tillage + disk harrow processing (with a number of 23 weeds $/ \mathrm{m}^{2}$ ) system and in the no tillage system (direct sowing, with a number of 30 weeds $/ \mathrm{m}^{2}$ ).

Compared with these two systems, in the chisel plough processing system (minimum tillage) and the classical tillage system the number of weeds was more reduced $(21,18$ weeds $/ \mathrm{m}^{2}$, respectively). Two weeks after the use of herbicides, the number of weeds diminished in all the tillage systems, except for the species X. strumarium and Che. album, that have been affected by herbicides only partially on the edge of the leaves (Table 3 ).

Nodules have an important role in the atmospheric nitrogen fixation, the quantity of the fixed nitrogen being proportional to the number of nodules. At the beginning of flowering, the number of nodules/ plant and their weight were determined for all the experimental factors (Tables 4).

Table 4. The average of nodules/plant and medium weight nodose/plant (flowering phenophase)

\begin{tabular}{|c|c|c|c|c|c|c|c|c|c|}
\hline \multirow{3}{*}{$\begin{array}{c}\text { TILLAGE } \\
\text { SOIL } \\
\text { SYSTEM }\end{array}$} & \multirow{3}{*}{ FERTILIZATION } & \multicolumn{8}{|c|}{ TREATMENTS } \\
\hline & & \multicolumn{2}{|c|}{ UNTREATED } & \multicolumn{2}{|c|}{ FUNGICIDE } & \multicolumn{2}{|c|}{ INSECTICIDE } & \multicolumn{2}{|c|}{$\begin{array}{l}\text { FUNGICIDE + } \\
\text { INSECTICIDE }\end{array}$} \\
\hline & & number & weight & number & weight & number & weight & number & weight \\
\hline \multirow{4}{*}{ CLASSIC } & $\mathrm{N}_{40} \mathrm{P}_{40}$ & 90 & 1.20 & 41 & 0.54 & 58 & 0.44 & 52 & 1.03 \\
\hline & $\mathrm{N}_{40} \mathrm{P}_{40}+$ GULLE & 68 & 1.07 & 59 & 0.62 & 71 & 0.72 & 88 & 0.99 \\
\hline & $\begin{array}{l}\mathrm{N}_{40} \mathrm{P}_{40}+\text { GREEN } \\
\text { FERTILIZER }\end{array}$ & 92 & 1.18 & 69 & 1.01 & 45 & 0.30 & 49 & 0.46 \\
\hline & $\begin{array}{l}\mathrm{N}_{40} \mathrm{P}_{40}+\text { GULLE }+ \\
\text { GREEN }\end{array}$ & 88 & 1.05 & 60 & 0.58 & 61 & 0.67 & 49 & 0.44 \\
\hline
\end{tabular}




\begin{tabular}{|c|c|c|c|c|c|c|c|c|c|}
\hline & FERTILIZER & & & & & & & & \\
\hline \multirow{4}{*}{$\begin{array}{l}\text { MINIMUM } \\
\text { TILLAGE } \\
\text { CHISEL }\end{array}$} & $\mathrm{N}_{40} \mathrm{P}_{40}$ & 38 & 0.22 & 31 & 0.19 & 63 & 0.53 & 70 & 1.02 \\
\hline & $\mathrm{N}_{40} \mathrm{P}_{40}+$ GULLE & 25 & 0.16 & 40 & 0.53 & 47 & 0.50 & 24 & 0.15 \\
\hline & $\begin{array}{l}\mathrm{N}_{40} \mathrm{P}_{40}+\text { GREEN } \\
\text { FERTILIZER }\end{array}$ & 47 & 0.50 & 40 & 0.44 & 51 & 0.61 & 52 & 0.42 \\
\hline & $\begin{array}{l}\mathrm{N}_{40} \mathrm{P}_{40}+\text { GULLE + } \\
\text { GREEN } \\
\text { FERTILIZER }\end{array}$ & 38 & 0.32 & 40 & 0.46 & 58 & 0.44 & 51 & 0.39 \\
\hline \multirow{4}{*}{$\begin{array}{l}\text { MINIMUM } \\
\text { TILLAGE } \\
\text { DISK }\end{array}$} & $\mathrm{N}_{40} \mathrm{P}_{40}$ & 38 & 0.35 & 40 & 0.41 & 90 & 0.22 & 34 & 0.36 \\
\hline & $\mathrm{N}_{40} \mathrm{P}_{40}+$ GULLE & 59 & 0.52 & 20 & 0.11 & 43 & 0.34 & 73 & 0.81 \\
\hline & $\begin{array}{l}\mathrm{N}_{40} \mathrm{P}_{40}+\text { GREEN } \\
\text { FERTILIZER }\end{array}$ & 48 & 0.34 & 27 & 0.25 & 20 & 0.17 & 73 & 0.74 \\
\hline & $\begin{array}{l}\mathrm{N}_{40} \mathrm{P}_{40}+\text { GULLE + } \\
\text { GREEN } \\
\text { FERTILIZER }\end{array}$ & 46 & 0.35 & 36 & 0.44 & 43 & 0.53 & 34 & 0.36 \\
\hline \multirow{4}{*}{$\begin{array}{c}\text { NO } \\
\text { TILLAGE }\end{array}$} & $\mathrm{N}_{40} \mathrm{P}_{40}$ & 34 & 0.36 & 25 & 0.24 & 44 & 0.31 & 45 & 0.52 \\
\hline & $\mathrm{N}_{40} \mathrm{P}_{40}+$ GULLE & 21 & 0.21 & 28 & 0.15 & 42 & 0.49 & 64 & 0.53 \\
\hline & $\begin{array}{l}\mathrm{N}_{40} \mathrm{P}_{40}+\text { GREEN } \\
\text { FERTILIZER }\end{array}$ & 39 & 0.35 & 19 & 0.12 & 25 & 0.09 & 49 & 0.47 \\
\hline & $\begin{array}{l}\mathrm{N}_{40} \mathrm{P}_{40}+\text { GULLE + } \\
\text { GREEN } \\
\text { FERTILIZER }\end{array}$ & 34 & 1.20 & 25 & 0.54 & 45 & 0.44 & 58 & 1.03 \\
\hline
\end{tabular}

It can be noticed that the number of nodules on the plant is smaller for the experimental variant treated with the extra dose of organic fertilizer compared with the $\mathrm{N}_{40} \mathrm{P}_{40}$ variant, and the highest number of nodules is reported at the classical tillage system.

The results regarding grain yield are presented in Table 5. The minimum tillage + chisel plough processing appears to improve soybeans yield with an efficiency of $6.5 \%$ (173 $\mathrm{kg} / \mathrm{ha}$ ). At no tillage system, the smallest yield was obtained. Supplementary fertilization with gulle can lead to a yield efficiency of up to $237 \mathrm{~kg} / \mathrm{ha}(9.5 \%)$, and complex supplementary fertilization with gulle and green manure significantly increased the yield $(340 \mathrm{~kg} / \mathrm{ha}-13.6 \%$ higher yield). Compared to the experimental variants without treatments, crop yield was positively affected by pest control during vegetation, production increasing with $221 \mathrm{~kg} / \mathrm{ha}$ (8.6\% higher) being recorded.

Table 5. The influence of the soil system tillage, fertilization and treatments on yield

\begin{tabular}{|c|c|c|c|c|}
\hline Variant & Yield kg/ha & Relative yield & Difference & Semnification \\
\hline \multicolumn{5}{|l|}{ A. Soil system tillage } \\
\hline Classic & 2648.91 & 100.0 & 0.00 & Mt. \\
\hline Minimum tillage Chisel & 2821.63 & 106.5 & 172.72 & $*$ \\
\hline Minimum tillage Disk & 2714.72 & 102.5 & 65.81 & - \\
\hline No tillage & 2365.28 & 89.3 & -283.63 & 00 \\
\hline LDS (p 5\%) & & & 102.82 & \\
\hline $\operatorname{LDS}(\mathrm{p} 1 \%)$ & & & 188.83 & \\
\hline LDS (p $0.1 \%)$ & & & 418.41 & \\
\hline \multicolumn{5}{|l|}{ B. Fertilization } \\
\hline $\mathrm{N}_{40} \mathrm{P}_{40}$ & 2493.75 & 100.0 & 0.00 & Mt. \\
\hline $\mathrm{N}_{40} \mathrm{P}_{40}+$ gulle & 2730.38 & 109.5 & 236.63 & $* *$ \\
\hline $\mathrm{N}_{40} \mathrm{P}_{40}+$ green fertilizer & 2492.50 & 99.9 & -1.25 & - \\
\hline $\mathrm{N}_{40} \mathrm{P}_{40}+$ gulle + green fertilizer & 2833.91 & 113.6 & 340.16 & $* * *$ \\
\hline LDS (p 5\%) & & & 140.58 & \\
\hline LDS (p 1\%) & & & 197.33 & \\
\hline LDS (p $0.1 \%)$ & & & 278.59 & \\
\hline Variant & Yield kg/ha & Relative yield & Difference & Semnification \\
\hline
\end{tabular}




\begin{tabular}{|l|c|c|c|c|}
\hline C. Treatments & 2586.19 & 100.0 & 0.00 & Mt. \\
\hline Untreated & 2566.00 & 99.2 & -20.19 & - \\
\hline Fungicide & 2590.72 & 100.2 & 4.53 & - \\
\hline Insecticide & 2807.63 & 108.6 & 221.44 & $* * *$ \\
\hline Fungicide + Insecticide & & & 116.60 & \\
\hline LDS (p 5\%) & & & 155.70 & \\
\hline LDS (p 1\%) & & & 203.15 & \\
\hline LDS (p 0.1\%) & & & \\
\hline
\end{tabular}

\section{CONCLUSIONS}

The experiment conducted at the Agricultural Research-Development Station Turda, in 2018, provided preliminary results for the development of an Integrated Management System (IMS) for phytosanitary soybean crop risks. Using complex methods of sustainable management with minimal impact on the environment, agroecosystems can be protected and soybean crop yield from the Transylvanian Plain can be optimized.

In 2018, soybean crop was attacked by different pests that decreased crop yield. The main species that attacked the soybean crop, at ARDS Turda, were the mite Tetranichus urticae and lepidopterans Autographa gamma, Mamestra suasa, M. oleracea, Agrotis segetum. Pathogens Peronospora manshurica and Pseudomonas glycinae were the most frequently observed.

The tillage system, fertilization and harmful organisms control are differently affecting plant growth and yield production. An increased grain yield was obtained when complex treatments were applied in the experimental variants based on minimum tillage system + chisel plough processing, with organic fertilization.

\section{ACKNOWLEDGEMENTS}

This paper was supported by a grant of the Romanian Ministry of Research and Innovation, CCCDIUEFISCDI, project number PN-III-P1-1.2-PCCDI-2017-0301, contract no. 28 PCCDI/2018 Integrated management system of the agroecosystem resistance against pests in order to promote sustainable agriculture under the conditions of climate change, within PNCDI III.

\section{REFERENCES}

AVOLA, G., TUTTOBENE, R., GRESTA, F., ABBATE, V. (2008). Weed control strategies for grain legumes. Agron. Sustain. Dev. 28, 389-395 https://doi.org/10.1051/agro:2008019.

BERCA, M. (2004). Combaterea integrată a buruienilor, Editura CERES, 471.

CHEŢAN, F., CHEŢAN, C., (2014). Cultivarea soiei în sistemul de agricultură conservativ şi rolul ei în protejarea mediului. Lucrări stiinţifice Bucureşti, Editura AGRIS - Revistele agricole SRL, București.

CHEȚAN, F., CHEȚAN, C., MUREȘANU, F. (2016). Stabilirea influenţei tehnologiei de cultivare a soiei asupra solului, producţiei şi eficienţa economică în zona Turda. Simpozion Economie Agrara si Dezvoltare Rurala - Realitati si Perspective pentru Romania, Bucureşti, 7, 124-129.

CHEȚAN, F., CHEȚAN C., ȘIMON, A., DEAC, V. (2017). Influența sistemului de fertilizare și de lucrare a solului asupra conservării apei în sol și producției la cultura de soia la S.C.D.A. Turda. Analele INCDA Fundulea, 86.

CHEŢAN, F., CHEŢAN, C., MUREŞANU, F., MALSCHI, D., SUCIU, V., BĂRDAŞ, M. (2019). Relaţia dintre condiţiile climatice, sistemul de lucrare a solului şi gradul de îmburuienare al culturii de soia, în zona Turda. Ghidul celei de-a XXIX-a ediții a simpozionului „Factori și procese pedogenetice din zona temperată” Iaşi septembrie 2019, Ed. Universităţii „,Alexandru Ioan Cuza”, Iaşi, 125-140. 
Georgescu, E., Cană, L., Gărgăriţă, R., Râşnoveanu, L. (2016). Cercetări privind combaterea păianjenului roşu comun (Tetranycus urticae) la cultura de soia, în sud-estul țării. Analele INCDA Fundulea, 84.

GRADILĂ, M., ENE, I., MIHALAŞCU, C. (2016). Sustainable use of preemergent herbicides in rape crops. Romanian Journal for Plant Protection, 9.

GRĂDILĂ, M., JALOBĂ, D. (2017). Effectiveness of post-emergence herbicides in vineyards in Ostrov, Constanta. Romanian Journal for Plant Protection, 10.

GRADILA, M., JALOBA. D. (2018). Weeds mapping from wheat crops. Scientific Papers. Series A. Agronomy, 61, 1.

IGNEA, M. (2017). 60 de ani de observaţii meteorologice în folosul cercetării agricole, la SCDA Turda. Agricultura transilvană, 27, Ed. Ela Design SRL Turda, 15-21.

IVAŞ, A.D., MUREŞANU, F. (2011). The abundance and dynamic of Lepidoptera pests from maize, soybean, sugar beet crops, in conditions of Agricultural Reasearch and Development Station Turda. Buletinul USAMV Cluj-Napoca, 68,1, 438-444.

IVAŞ, A., MUREŞANU, F. (2013). Researches on the monitoring of the most frequent pests from maize and soybean crops in the conditions at ARDS Turda. The $12^{\text {th }}$ International Symposium "Prospects for the $3^{\text {rd }}$ Millennium Agriculture, 26- 28 September 2013, Cluj-Napoca, 1, 276-277.

MALSCHI, D. (1980). Apariția, dinamica și combaterea dipterelor dăunătoare culturilor de grâu în Romania. Producția vegetalã - Cereale si Plante Tehnice, 8, 43-48.

MALSCHI, D. (2007). Mediu - agricultură - dezvoltare durabilă şi managementul integrat al dăunătorilor agroecosistemelor cerealiere. Edit. Argonaut, Cluj-Napoca, 186.

MALSCHI, D. (2009). Integrated pest management in relation to environmental sustainability. Part I. Ecological management of wheat pests. Course notes and practical applications. En. Manual online. Faculty of Environmental Sciences, Babeş-Bolyai University, Cluj-Napoca. Bioflux Publishing House, Cluj-Napoca, 200.

MALSCHI, D. (2014). Mediu-Biotehnologie-Dezvoltare Durabilă. Biotehnologii şi depoluarea sistemelor ecologice. Editura Bioflux, 190.

MALSCHI, D., MUSTEA, D. (1995). Protection and use of entomophagous arthropod fauna in cereals. Romanian Agricultural Research, 4, 93-99.

MALSCHI, D., MUSTEA, D. (1997). Investigatii asupra importantei entomofagilor pradatori in agroecosistemele cerealiere din Transilvania. Analele ICCPT Fundulea, 64,253-266.

MALSCHI, D., MUREŞANU, F., IVAŞ, A. (2013). Evaluarea potenţialului dăunătorilor culturilor de câmp din Câmpia Transilvaniei. Analele INCDA Fundulea, 81, 1, 167-183.

MALSCHI, D., MUREȘANU, F., TĂRĂU, A.D., VĂLEAN, A.M. (2017). Șase decenii de cerecetări orientate spre prevenirea și combaterea dăunătorilor din culturile de câmp la SCDA Turda. Contribuții ale cercetării științifice la dezvoltarea agriculturii, 7, 285-322.

MALSCHI, D., TĂRĂU, A.D., VĂLEAN, A.M., ȘOPTEREAN, L., DĂRAB, I., KADAR, R., CHEȚAN, F., MUREȘANU,F., CHEŢAN, C., TRITEAN,N. (2018). Integrated pest management in relation to environmental sustainability. Part II. Wheat pest management under the dynamics of agroecological changes in Transylvania. Bioflux Publishing House Cluj-Napoca, 83.

MUREŞAN F., CIOCHIA, V., MUSTEA, D. (1989). Contribuţii la cunoaşterea dinamicii celor mai importante specii de Lepidoptere - Noctuidae cu ajutorul capcanelor feromonale în Câmpia Transilvaniei (zona Turda). Lucrãri ştiințifice, Sfecla de zahãr, ICPCSZ Fundulea, 23, 225-242.

MUREŞAN, F., MUSTEA, D., ROŞCA, I., OPREAN, I., MATEIAŞ, M.C. (1998). Dinamica apariţiei unor lepidoptere dãunãtoare culturilor de câmp în condiţiile podişului Transilvaniei. Probleme de Protectia Plantelor, 26, 2, 209 - 219.

MUREŞAN, F., ROŞCA, I., GYORFY, M. (2002). The importance of synthetic sexual pheromones in the IPM for agricultural crops in Transylvania. Buletinul USAMV Cluj-Napoca, 225.

MUREŞAN, F., TĂRĂU, A. (2013). Câteva informaţii privind păianjenul roşu comun (Tetranychus urticae Koch.), prezent în cultura de soia la SCDA Turda. Agricultura Transilvană , 19, 58-63.

MUREŞAN, F., MALSCHI, D., SUCIU, L. (2014). Soia în Transilvania - boli şi dăunători. Agricultura Transilvană, 20. 
MUSTEA, D., TATARU, V. (1970). Musca Hylemyia cilicrura Rd., daunator al culturilor de leguminoase. Ferma si inteprinderea agricola de stat, 7/1973, 18-19.

PERJU, T., MALSCHI, D. (2001). Familia Anthomyiidae. Tratat de zoologie agricolă. 5, 287-337.

POPOV, C., BĂRBULESCU, A., VILĂU, F., TROTUŞ, E., MALSCHI, D., VASILESCU, S., TRAŞCĂ, G. (2003). Influenţa secetei asupra evoluţiei populaţiilor de insecte daunatoare din culturile de câmp. Probleme de protecția plantelor, 31,1,49-66.

RUSU, T. (2014). Energy efficiency and soil conservation in conventional, minimum tillage and notillage. International Soil and Water Conservation Research, 2, 4, 42-49.

SARTORATO, I., BERTI, A., ZANIN, G. (1996). Estimation of economic thresholds for weed control in soybean (Glycine max (L.) Merr.). Crop Protection.

STAN, N., MUNTEANU, N., STAN, T. (2003). Legumicultură, 3, Ed. Ion Ionescu de la Brad, Iaşi.

SUCIU, L., MUREŞANU, F., IVAŞ, A., PĂCURAR, A.M. ( 2014). The pathogens and lepidopteran pests corn and soybeans in the Transylvanian plain, The 13th International Symposium "Prospects for the 3rd millennium agriculture".

TROTUŞ, E., BUBURUZ, A.A., POCHIŞCANU, S.F., POMOHACI, T. (2014). Organismele dăunătoare din culturile de soia şi măsurile de prevenire şi combatere. Analele INCDA Fundulea, 82. 